\title{
An Alternative Bioassay for Synchytrium endobioticum Demonstrates the Expression of Potato Wart Resistance in Aboveground Plant Parts
}

\author{
B. T. L. H. van de Vossenberg, ${ }^{1,2 \dagger}$ M. P. E. van Gent-Pelzer, ${ }^{1}$ M. Boerma, ${ }^{3}$ \\ L. P. van der Gouw, ${ }^{2}$ T. A. J. van der Lee, ${ }^{1}$ and J. H. Vossen ${ }^{4}$ \\ ${ }^{1}$ Wageningen UR, Droevendaalsesteeg 1, Biointeractions and Plant Health, 6708 PB, Wageningen, The Netherlands \\ ${ }^{2}$ Dutch National Plant Protection Organization, National Reference Centre, Geertjesweg 15, 6706 EA, Wageningen, The Netherlands \\ ${ }^{3}$ Hilbrands Laboratorium BV, Kampsweg 27, 9418 PD, Wijster, The Netherlands \\ ${ }^{4}$ Wageningen UR, Droevendaalsesteeg 1, Plant Breeding, 6708 PB, Wageningen, The Netherlands \\ Accepted for publication 23 February 2019.
}

\begin{abstract}
The obligate biotrophic chytrid species Synchytrium endobioticum is the causal agent of potato wart disease. Currently, 39 pathotypes have been described based on their interaction with a differential set of potato varieties. Wart resistance and pathotyping is performed using bioassays in which etiolated tuber sprouts are inoculated. Here, we describe an alternative method in which aboveground plant parts are inoculated. Susceptible plants produced typical wart symptoms in developing but not in fully expanded aboveground organs. Colonization of the host by $S$. endobioticum was verified by screening for resting spores by microscopy and by molecular techniques using TaqMan polymerase chain reaction and RNAseq analysis. When applied to resistant plants, none of these symptoms were detectable. Recognition of S. endobioticum pathotypes by differentially resistant potato varieties was identical in axillary buds and the tuber-based bioassays. This suggests that $S$. endobioticum resistance genes are expressed in both etiolated "belowground" sprouts and green aboveground organs. RNAseq

analysis demonstrated that the symptomatic aboveground materials contain less contaminants compared with resting spores extracted from tuber-based assays. This reduced microbial contamination in the aboveground bioassay could be an important advantage to study this obligate biotrophic plant-pathogen interaction. Because wart resistance is active in both below- and aboveground organs, the aboveground bioassay can potentially speed up screening for S. endobioticum resistance in potato breeding programs because it omits the requirement for tuber formation. In addition, possibilities arise to express $S$. endobioticum effectors in potato leaves through agroinfiltration, thereby providing additional phenotyping tools for research and breeding.

Keywords: genetics and resistance, molecular verification, mycology, pathogen proliferation, plant-pathogen interaction, RNAseq, species richness, techniques.
\end{abstract}

Synchytrium endobioticum is a soilborne obligate biotrophic fungal pathogen causing potato wart disease, and belongs to the basal fungal division of Chytridiomycota. The disease is characterized by hypertrophic growth and callus-like wart structures on potato tubers (Curtis 1921). Warts can vary significantly in size from less than pea-sized proliferations to the size of a fist (Hampson 1993). In the infected tissue, summer sporangia are developed, leading to new infections. Belowground warts are white to brown, whereas aboveground malformed tissues are green. Both types of wart turn black upon host tissue decay, which coincides with enhanced resting (or winter) spore formation. Decomposition of warted tissue allows release of these spores into the surrounding soil. Resting spores have been reported to remain viable and infectious in fields without potato cultivation for decades

†Corresponding author: B. T. L. H. van de Vossenberg;

b.t.1.h.vandevossenberg@nvwa.nl

Funding: This research (1406-056) is financially supported by the Dutch Topsector Horticulture \& Starting Materials. Within the Topsector, private industry, knowledge institutes, and the government are working together on innovations for sustainable production of safe and healthy food and the development of a healthy green environment (https://topsectortu.nl/nl/integrated-genomics-and-effectoromics-impulsepotato-wart-resistance-management-and-breeding).

*The $e$-Xtra logo stands for "electronic extra" and indicates that seven supplementary figures and four supplementary tables are published online.

The author(s) declare no conflict of interest.

Copyright (C) 2019 The Author(s). This is an open access article distributed under the CC BY 4.0 International license.
(Przetakiewicz 2015b). The original description of S. endobioticum by Schilberszky (Schilberszky 1896) was based on infected potato tubers but all parts of the shoot system can be infected, while the root system is immune (Weiss 1925).

In the early 1900 s, potato varieties resistant to $S$. endobioticum were discovered (Moore 1957), which represented the start of breeding programs for potato wart resistance. Until 1941, only a single pathotype was recognized but, currently, 39 pathotypes (races) of the pathogen are acknowledged based on their interaction using a set of differential potato varieties (Baayen et al. 2006; Çakır et al. 2009; Przetakiewicz 2015a), of which pathotypes 1(D1), $2(\mathrm{G} 1), 6(\mathrm{O} 1)$, and $18(\mathrm{~T} 1)$ are considered to be of main importance in Europe. In Canada, mainly pathotypes 2(G1) and 6(O1) have been reported (Hampson 1993).

Once introduced into fields with potato cultivation, there are no effective chemical agents to control the disease (Hampson 1988). Strict phytosanitary measures combined with the use of resistant potato varieties are the only successful strategy to prevent introduction and spread of the pathogen. For these reasons, S. endobioticum has a quarantine status in most countries worldwide (Smith et al. 1997), and is included on the Health and Human Services and United States Department of Agriculture select agent list.

Studying biotrophic pathogens depends heavily on the quality of the bioassays to study the interaction between pathogens and their hosts. In addition, soilborne obligate biotrophic organisms represent a unique challenge, because the complex microbiome of the soil is an obscure and possibly disturbing component in the interaction. Bioassays are also exploited in numerous pathosystems to determine pathogen virulence or to group pathogens in races or pathotypes. Grouping of S. endobioticum isolates into pathotypes 
is of major importance and fundamental to phytosanitary measures to restrict the spread of the disease (OEPP/EPPO 2017). Two different bioassays are currently used for pathotype grouping-Spieckermann (Spieckermann 1924) and Glynne-Lemmerzahl (Glynne 1925; Lemmerzahl 1930; Noble and Glynne 1970)_of which the latter is most frequently used in Europe (Flath et al. 2014). In Spieckermann assays, composts containing resting spores are used as inoculum whereas, in the Glynne-Lemmerzahl assays, fresh wart cuttings, which mainly contain summer sporangia, serve as inoculum. Apart from pathotype identification, these bioassays are used in breeding programs to determine the resistance or susceptibility of new potato genotypes to selected S. endobioticum pathotypes. Even though the Spieckermann and Glynne-Lemmerzahl bioassays are routinely applied for pathotyping and resistance screening, these assays remain challenging even though international programs were established to harmonize and optimize these bioassays. Alternatives to these tuberbased assays have been described. Hampson used micropropagated plantlets and showed that these produced more consistent infection percentages and were more sensitive than the tuber-based assays (Hampson 1992; Hampson et al. 1997). In 1962, Ullrich used a leafbased bioassay to study the morphology of malformed host tissues (Ullrich 1962). Nevertheless, these methods were never adopted by the research community.

Without culturing options, and because no transformation protocols are described for the obligate biotrophic S. endobioticum, heterologous systems need to be used to study the plant-pathogen interaction on a molecular level. Transient expression of pathogen genes in plants with the leaf-based agroinfiltration system has been used in other pathosystem to elucidate their role in pathogenicity (Vleeshouwers et al. 2011). Because resistance to plant pathogens in potato can occur in an organ-specific manner (Millett et al. 2015), similar expression of potato wart resistance in aboveground plant parts compared with the tuber-based bioassays is key to using the leaf-based agroinfiltration system for $S$. endobioticum.

Here, we describe a bioassay targeting aboveground plant parts (i.e., axillary buds) that was developed to (i) determine whether potato resistance $(R)$ genes are active in aboveground plant parts producing the same differential responses as the tuber-based assays and (ii) eliminate the complex microbial contamination that is associated with the soil matrix from the potato-S. endobioticum interaction to generate more suitable material to study the interaction on a molecular level. Finally, we discuss the potential use of the aboveground bioassay to speed up screening for $S$. endobioticum resistance in breeding programs.

\section{MATERIALS AND METHODS}

Fungal materials. Fresh warts of pathotypes used as inoculum in the aboveground bioassay were obtained from pot tests with the susceptible potato variety Deodara. Several 16-by-16-cm pots filled with potting soil amended with composts of pathotypes 1(D1) isolate HLB 11-11 (approximately 1,200 spores/g), 2(G1) isolate HLB 03-08 (approximately 1,500 spores/g), 6(O1) isolate HLB 1011 (approximately 600 spores/g), and 18(T1) isolate HLB 05-08 (approximately 1,800 spores/g) in a 1:10 ratio for compost-potting soil. These isolates are also used in national resistance testing programs from The Netherlands, and reactions on differential potato varieties Deodara, Producent, Saphir, Miriam, Delcora, and Belita were consistent with those described in European and Mediterranean Plant Protection Organization (EPPO) standard PM7/28(1) (OEPP/EPPO 2004) (Supplementary Table S2). Pots were kept separated per pathotype in a quarantine glasshouse in which temperatures were kept below $25^{\circ} \mathrm{C}$ with a light regime of $16 \mathrm{~h}$ of light and $8 \mathrm{~h}$ of darkness. Shoots were cut back regularly to keep the plants below approximately $50 \mathrm{~cm}$ in height until harvesting the warts (typically 8 to 12 weeks after inoculation).

Aboveground bioassay. In all, 10 Deodara and 8 Tomensa plants, both susceptible to pathotype 1(D1), and 11 Kuba plants resistant to pathotype 1(D1) were tested with 14 different treatment combinations (including mock treatments) to optimize the procedure. Optimization parameters included inoculum type (fresh wart cuttings and compost), inoculation sites (axillary buds and leaves), fixing the inoculum (household plastic and sticky tape), and incubation conditions (in the greenhouse, with temperatures kept below $25^{\circ} \mathrm{C}$, inoculated plants were placed in a closed tent of transparent foil to ensure maximum humidity, as described below; or in a climate chamber maintained at approximately $16^{\circ} \mathrm{C}$ and $80 \%$ relative humidity [RH], without illumination). The overview of varieties and parameters used (Fig. 1) was created with the UpSet visualization tool (Lex et al. 2014).

The following procedure is the result of optimization experiments performed in early spring 2016. Potato plants were grown from tubers in 16-by-16-cm pots with potting soil containing Osmocote (R) Exact slow-release grains for nutrients (ICL Specialty Fertilizers) in March to April under greenhouse conditions described above. When plants were 20 to $40 \mathrm{~cm}$ tall, typically after 3 to 4 weeks, they were inoculated with small (5- to 10-mm) cuttings of fresh warts. Precautions were taken to ensure that the inoculum was as "clean" as possible. First, only young, fresh warts that did not yet show any sign of decay were taken from the Spieckermann assay and were thoroughly rinsed with tap water to remove any remaining soil. Finally, visually clean cuttings were taken from the rinsed fresh warts and used as inoculum. Mock-treated plants were included for each of the varieties tested. Axillary buds were moistened with a fine mist, after which wart cuttings were placed with the uncut surface facing toward early developing buds, ensuring that they were in close proximity to the plant tissue. Inoculated buds were moistened again and wrapped in household plastic to hold them in place and to maintain a moist environment to facilitate infection. Inoculated buds were marked with a unique label and, after inoculation, plants were placed on a greenhouse table with a moisture-retaining cloth under a bespoke 100-by-96-by-210-cm (height by depth by width) frame fitted with 0.5 -mm transparent foil (Supplementary Fig. S1). The cloth and pots were watered intensively, and the plastic was lowered over the frame to create a closed environment with RH up to $100 \%$. The plants remained untouched for a week, after which the inoculum was removed and apical shoot and noninoculated axillary shoots were cut to stimulate growth of the inoculated axillary buds. Plants were watered regularly to maintain a $100 \% \mathrm{RH}$ environment under the plastic, and were regularly inspected for signs of malformation of the plant tissue. After 4 weeks, the first symptoms became apparent, and plants were kept until 8 weeks after inoculation. Selected symptomatic and asymptomatic buds for all variety-pathotype combinations, including mock-treated plants, were sampled 30 to 59 days postinoculation (dpi) for microscopy and molecular testing. Plant were scored visually as symptomatic when they showed clear signs of malformation, or asymptomatic when no malformation was observed. Slight malformations that could be the result of proliferation of the pathogen or stress caused by the conditions in the greenhouse (e.g., high humidity and axillary buds being wrapped in household plastic) were scored as "unclear phenotype".

In the following year (2017), varieties from EPPO standard PM7/ 28 (2) (OEPP/EPPO 2017) Deodara, Producent, Talent, Saphir, and Belita (at least three plants per variety) were used in combination with S. endobioticum pathotypes 1(D1), 2(G1), 6(O1), and 18(T1). Buds showing early malformations for each pathotype tested on variety Deodara were sampled 24 dpi for RNAseq analysis. These samples were flash frozen with liquid nitrogen and stored at $-80^{\circ} \mathrm{C}$ until RNA extraction.

DNA extraction and $S$. endobioticum quantification. DNA was extracted from approximately 50 to $200 \mathrm{mg}$ of plant material using the Wizard Magnetic DNA Purification System for Food (Promega Corp.) following the manufacturer's instructions. Plant material was homogenized at room temperature in $400 \mu \mathrm{l}$ of Lysis Buffer A and $200 \mu \mathrm{l}$ of Lysis Buffer B with three 3.2-mm stainless steel beads using a Precellys Evolution (Bertin 
Instruments $)$ at $5,000 \mathrm{bpm}$ for $45 \mathrm{~s}(3 \times 15 \mathrm{~s}$ and 10 -s pause in between) prior to DNA extraction. S. endobioticum DNA was quantified using an $S$. endobioticum specific real-time polymerase chain reaction (PCR) with plant coxl internal control (van GentPelzer et al. 2010). Boxplots, biplots, and statistical analyses were performed with GenStat v19.1 (VSN International).

RNA extraction and Illumina sequencing. Plant material was homogenized dry in stainless-steel microvials (BioSpec) with 3.2-mm beads, and cooled with liquid nitrogen using a Precellys Evolution (Bertin Instruments) homogenizer at 8,000 rpm for $15 \mathrm{~s}$. Stainless-steel microvials were cooled again with liquid nitrogen and homogenized at $8,000 \mathrm{rpm}$ for another $15 \mathrm{~s}$ prior to RNA extraction. Homogenized plant material was lysed in RLC buffer with $\beta$-mercaptoethanol. Total RNA was extracted using the RNeasy plant mini kit (Qiagen) following the manufacturer's instructions. Extracted RNA was DNase treated using the DNA-free DNA removal kit (AM190; Thermo Fisher Scientific, MA, USA) and quantified with the Quant-iT RiboGreen RNA (Thermo Fisher) on a plate reader (Infinite 200 PRO; Tecan Life Sciences). Poly-A enriched Illumina RNAseq libraries were prepared with TruSeq RNA Library Prep Kit v2 (Illumina) and sequenced on a HiSeq2500 (Illumina).

Expression of $S$. endobioticum genes and assessment of represented taxa. RNAseq data obtained from aboveground plant parts were compared with RNAseq data derived from belowground infected plant parts. The belowground-derived RNAseq data were taken from B. T. L. H. van de Vossenberg, S. Warris, H. D. T. Nguyen, M. P. E. van Gent-Pelzer, D. L. Joly, H. C. van de Geest, P. J. M. Bonants, D. S. Smith, C. A. Lévesque, and T. A. J. van der Lee (unpublished) (SRA: SRR8074754 and SRR8074755), and were obtained from resting spores which were extracted and purified from fresh wart tissue, as described by Bonants et al. (2015). Libraries for the belowground RNAseq datasets were prepared with either a polyA enrichment or ribosomal plant RNA depletion (Supplementary Table S1). Reads were mapped to the coding sequences and genomes of pathotype 1(D1) S. endobioticum (MB42) (National Center for Biotechnology Information [NCBI] accession QEAN00000000, version 1.0) in CLC Genomics Workbench using the RNA-seq analysis tool (length fraction $=0.8$, similarity fraction $=0.9$, counting paired reads as two), and expression levels were reported as transcripts per kilobase million (TPM) per gene. Unmapped reads were collected and mapped to the Solanum tuberosum subsp. phureja (DM v3.0) genome (The Potato Genome Sequencing Consortium 2011) using the same tool and settings, after which reads that did not map to either Synchytrium endobioticum MB42 v1.0 or Solanum tuberosum DM v3.0 were assembled de novo in CLC (word size: automatic, bubble size: automatic, scaffolding: on). Scaffolds were updated using a read mapping approach (similarity fraction $=0.8$, length fraction $=0.9$ ). Contigs smaller than $200 \mathrm{bp}$ and those still producing significant megablast hits $\left(\mathrm{e}\right.$-value $\left.<1 \mathrm{e}^{-50}\right)$ with the Synchytrium endobioticum LEV6574 v1.0 (NCBI accession QEAM00000000, version 1.0) or DMv3.0 were discarded, and the remaining sequences were used as input for a taxonomy identification pipeline. This pipeline consisted of a blastn (which is part of the BLAST+ v2.6.0 package) (Camacho et al. 2009) analysis in a local NCBI nr/nt database (download date: 24 September 2018). Sequences producing no hit with blastn (e-value $<1 \mathrm{e}^{-50}$ ) were selected and were further analyzed using Diamond (Buchfink et al. 2015). Taxa represented in the blastn and Diamond output were visualized using Krona (Ondov et al. 2011).

\section{RESULTS}

Optimization experiments. In total, 153 aboveground plant parts were treated, of which 101 were inoculated with fresh wart cuttings, 31 were inoculated with compost containing resting
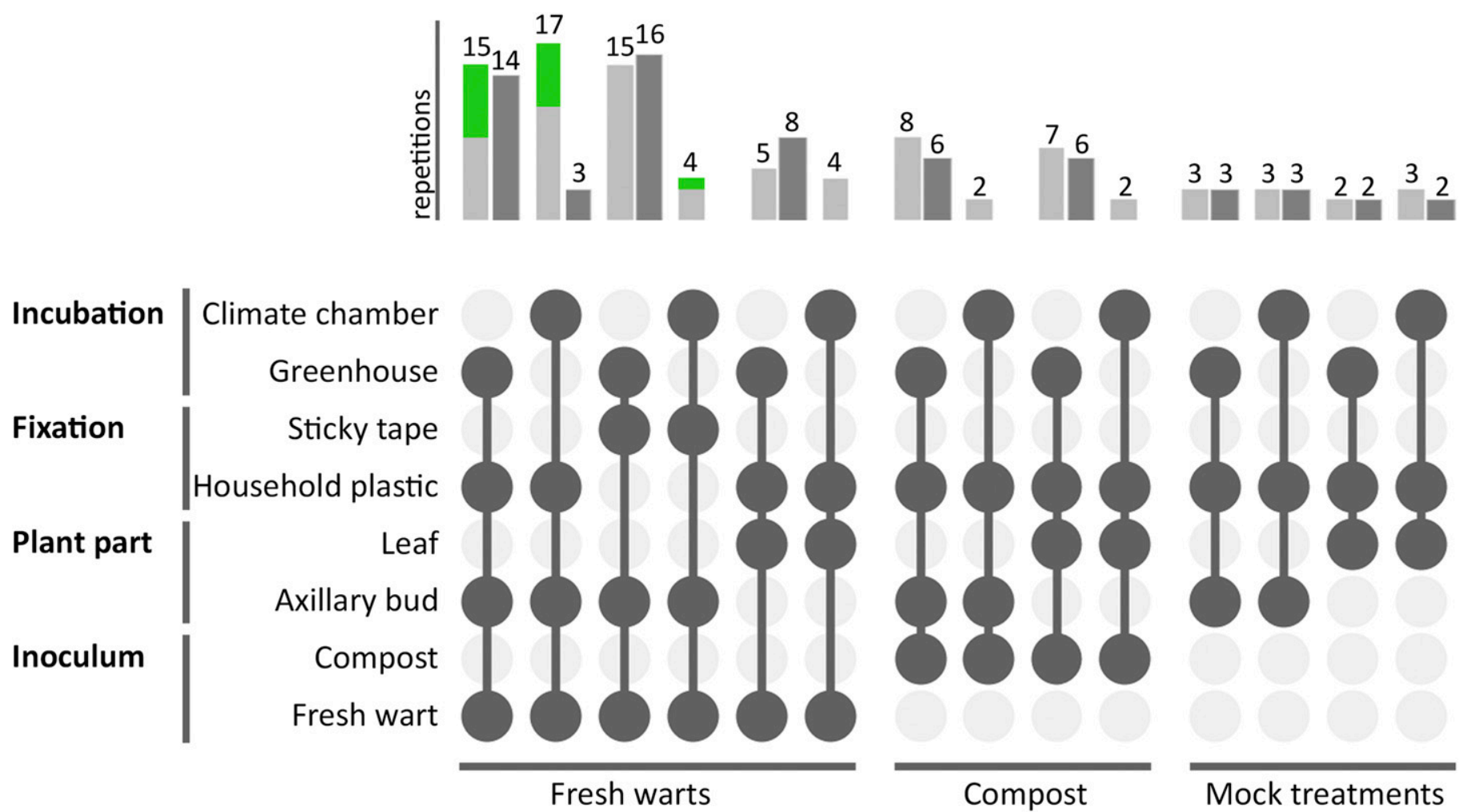

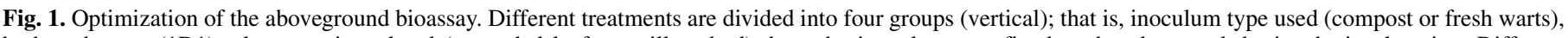

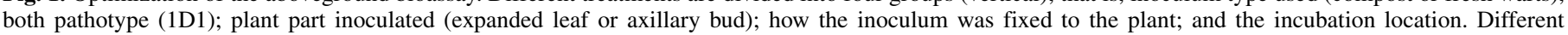

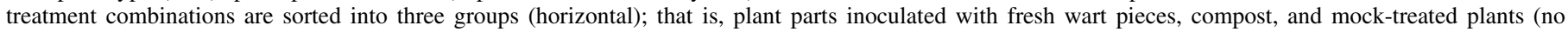

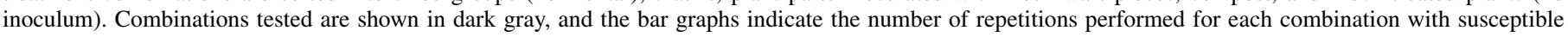

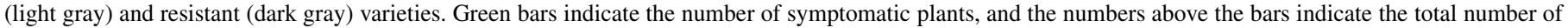
repetitions performed. 
spores, and 21 inoculations did not have any inoculum (i.e., mock treatments) (Fig. 1). From the combinations with inoculum, 53 were on variety Kuba, which is resistant to pathotype 1(D1), whereas 79 were performed with the varieties Deodara and Tomensa, which are susceptible to pathotype 1(D1).

None of the mock-treated or inoculated resistant plants produced any symptoms, whereas 14 inoculated aboveground plant parts of the susceptible plants (18\%) produced malformed tissue. When further differentiating the formation of malformed tissues according to their respective treatments, wart-inoculated axillary buds wrapped with household plastic produced the highest percentage of symptoms regardless of their incubation method: 47 and $35 \%$ of the inoculated axillary buds for plants incubated under transparent foil and in the climate chamber, respectively. None of the inoculated leaves resulted in malformation of the plant tissue. Similarly, none of the compost-inoculated plant parts produced any symptoms.

Proliferation of the pathogen was confirmed using a speciesspecific TaqMan PCR, which resulted in significantly lower (general analysis of variance [ANOVA], $P<0.001$ ) quantification cycle $(\mathrm{Cq})$ values for inoculated plant parts showing symptoms $\left(\mathrm{Cq}_{\text {mean }}=17.1 \pm 3.1\right)$ compared with mock-treated plants $(33.2 \pm$ 3.2) and inoculated plant parts without signs of the disease (33.1 \pm 2.7) (Fig. 2). In the susceptible varieties Deodara and Tomensa, seven inoculated plant parts were scored as "unclear" (Supplementary Fig. S2). Two of these samples produced $\mathrm{Cq}$ values consistent with proliferation of the pathogen, whereas the others produced $\mathrm{Cq}$ values similar to the mock-treated plants and inoculated plant parts showing no visual symptoms. A bimodal distribution is obtained for Cq values obtained from infected plant parts compared with those obtained from healthy plant parts (Supplementary Fig. S3). It was concluded that treatment combination "wart, household plastic, bud, greenhouse" is the most efficient one and is further referred to as the "aboveground bioassay".
Aboveground inoculation of EPPO differential set. Five potato varieties (i.e., Deodara, Producent, Talent, Saphir, and Belita) listed in the EPPO differential set for S. endobioticum pathotype identification with the Glynne-Lemmerzahl method (OEPP/EPPO 2017) were inoculated using the aboveground bioassay. In total, 233 axillary buds were inoculated with fresh warts on Deodara obtained with pathotypes 1(D1), 2(G1), 6(O1), and 18(T1). Two months after inoculation, pathotype 1(D1) produced symptoms on Deodara on the majority (72\%) of inoculated axillary buds but not on resistant varieties (Table 1). Pathotype 2(G1) produced clear symptoms on varieties Deodara, Producent, and Saphir. For Deodara and Producent, the success rate of the inoculation was higher compared with Saphir: 47, 56, and $25 \%$, respectively. In Talent inoculated with pathotype 2(G1), two of the replicates were scored as "unclear phenotype" whereas the other eight produced no visible symptoms. Pathotype 6(O1) produced symptoms on Deodara (25\%) and Producent (83\%), of which the latter had the highest success rate for any of the pathotype-variety combinations tested. Similar to pathotype 2(G1), pathotype $6(\mathrm{O} 1)$ only produced four slight malformations on Talent. Pathotype 18(T1) produced malformed tissues on varieties Deodara (46\%), Producent (58\%), and Talent (33\%). Inoculated plant parts sampled 35 dpi for microscopy and molecular verification showed the presence of spores in the malformed tissue (Supplementary Fig. S4).

Verification of pathogen proliferation using the S. endobioticumspecific TaqMan assay on the EPPO differential set yielded similar results compared with the $\mathrm{Cq}$ values obtained in the optimization experiments. The $S$. endobioticum-specific TaqMan PCR could be used to distinguish healthy plant parts from infected plant parts (Fig. $3)$. Symptomatic plant samples from susceptible varieties produced significantly (general ANOVA, $P<0.001$ ) lower $\mathrm{Cq}$ values compared with mock-treated plants and resistant varieties with no
A

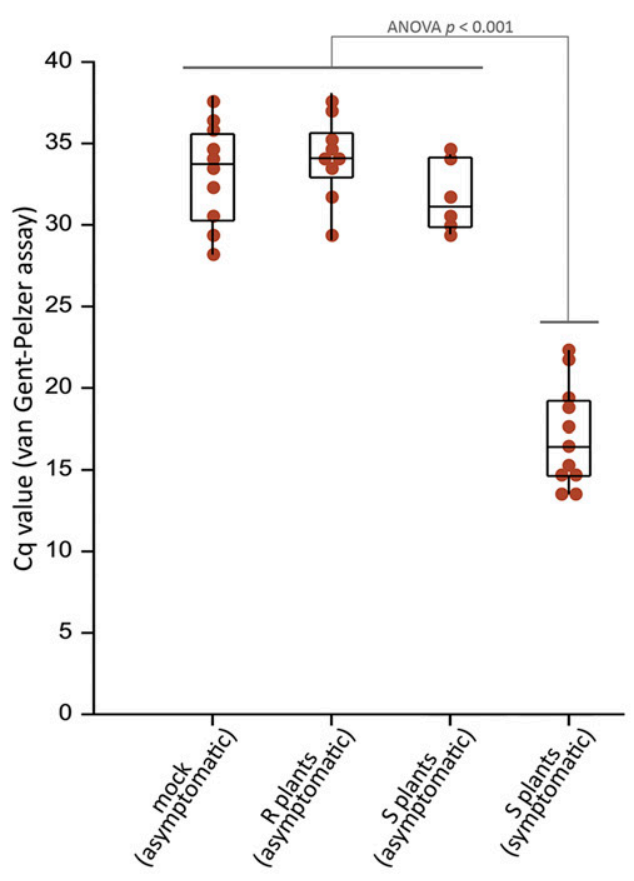

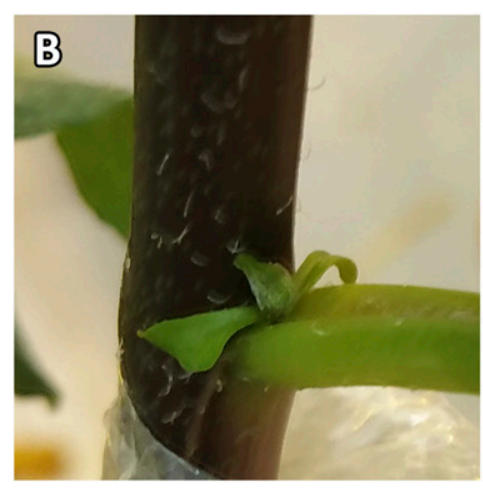
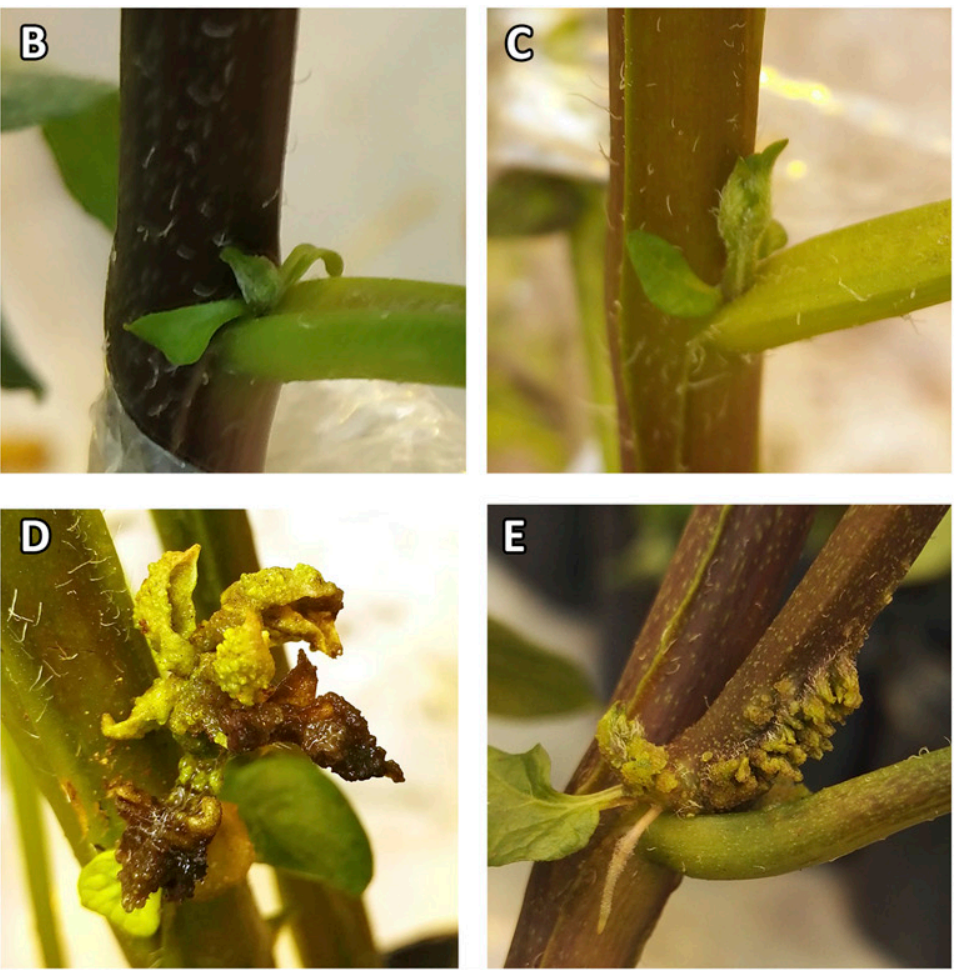

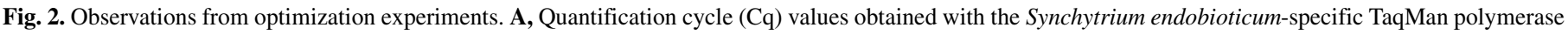

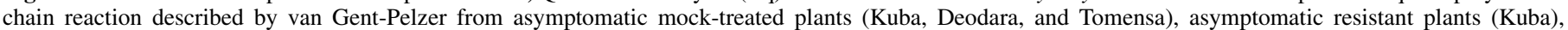

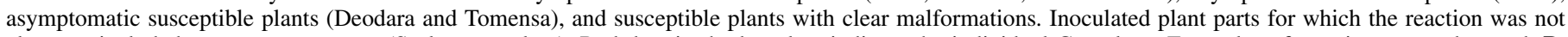

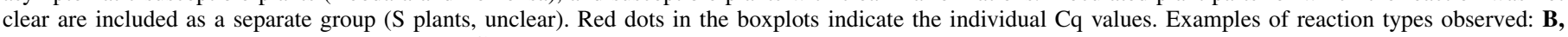

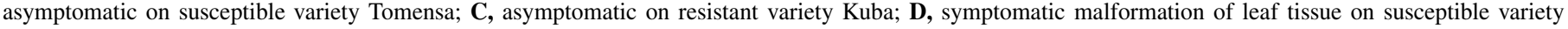
Deodara; and E, symptomatic malformation of shoot tissue and aerial root formation on susceptible variety Deodara. 
symptoms (i.e., $\mathrm{Cq}_{\text {means }} 16.4 \pm 1.8$ versus $35.5 \pm 2.3$ and $30.8 \pm 3.1$, respectively). Of the 11 samples initially scored as unclear, 9 produced $\mathrm{Cq}$ values consistent with proliferation of the pathogen. These included both susceptible interactions (pathotype 18(T1)-inoculated Deodara plants) and interactions that are formally described as slightly susceptible (pathotype 2(G1)- and 6(O1)-infected Talent plants).

Interestingly, in some cases, malformed tissue regrew after removal of the warted tissue for sampling at $35 \mathrm{dpi}$ (Fig. 4). The new outgrowth of the malformed tissue appeared 24 days (59 dpi) after the first sampling on varieties Deodara and Producent. For Deodara, a single pathotype 1(D1)- and a single pathotype 2(G1)-inoculated site showed outgrowth of new malformed tissue, whereas, for Producent, three 2(G1)-, a single 6(O1)-, and three 18(T1)inoculated sites showed new outgrowth. This suggests that not all of the affected tissue was removed, allowing new outgrowth of malformed tissue. In addition, the development of warts on belowground plant parts, which were not actively inoculated, of five Deodara and two Producent in combination with pathotypes 1(D1) and 2(G1) became apparent 59 dpi (Supplementary Fig. S5).

RNAseq analysis. Three samples per pathotype from Deodara axillary buds exhibiting early signs of malformation were subjected to RNAseq. In each sample, expression of S. endobioticum genes was found (Table 2; Supplementary Table S3). Mapping to the RNAseq reads to the MB42 reference genome showed expression for the $S$. endobioticum household gene elongation factor $1 \alpha$ $($ SeEF1 $\alpha$ ) (SeMB42_g00306) ranging from 140 to 2,429 TPM. In resting spores obtained from fresh warts on tuber sprouts in an independent inoculation experiment, SeEF1 $\alpha$ TPM values ranged from 408 to 917 . For the malformed axillary buds, 0.4 to $6.4 \%$ of all generated reads mapped to $S$. endobioticum, whereas the majority of reads mapped to its host potato (84.1 to $94.5 \%)$. This contrasts to resting spores extracted from fresh belowground warts which have more reads mapping to $S$. endobioticum (16.1 to $42.5 \%$ ) and very few reads mapping to potato (0.6 to $9.2 \%)$. In the malformed axillary buds, 4.0 to $9.6 \%$ of all reads remain unmapped. In contrast, the resting spores extracted from fresh warts on tubers that have 56.9 to $81.9 \%$ of all reads remain unmapped. The unmapped reads were believed to be derived from other biological agents represented in the aboveground samples and belowground samples To putatively identify these agents, de novo assemblies were performed of the unmapped reads, which resulted in a significantly ( $t$ test, $P<0.001)$ higher number of de novo assembled transcripts for the samples derived from resting spores from fresh warts.

Of the de novo assembled transcripts, $2.2 \%$ still produced significant (e-value $<10^{-20}$ ) hits with either the $S$. endobioticum pathotype 6(O1) LEV6574 genome or the SolTub v3.0 potato genome, and were removed from the analysis. For the remaining 264,128 contigs, approximately $90 \%$ could be identified as eukaryotic (further specified as fungal, metazoan, ciliates, and plant), bacterial, or viral (Fig. 5; Supplementary Table S4). For the aboveground-derived samples, on average, a quarter of all contigs were believed to originate from the host plant. This in contrast to the belowground-derived samples, which had very low percentages $(<0.5 \%)$ of plant hits. Species from the ciliate subphylum Intramacronucleata were abundantly present in both aboveground and belowground samples but, in the latter category, they represented only a very small portion of all transcripts. Almost no non-S. endobioticum Chytridiomycota hits were obtained with the

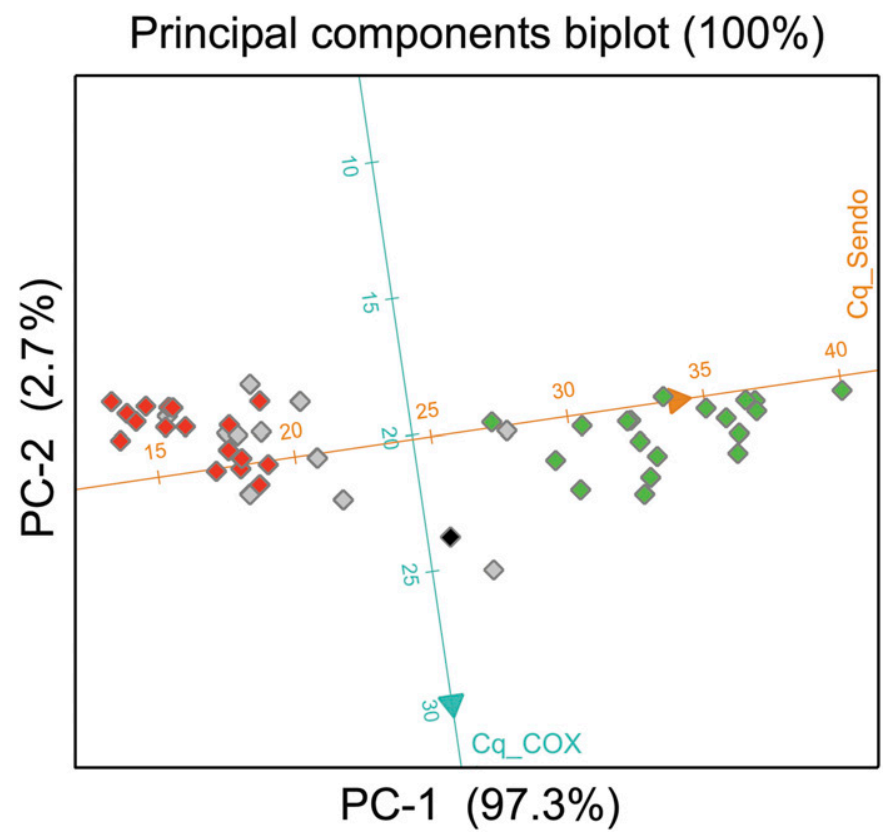

Fig. 3. Biplot of quantification cycle (Cq) values from aboveground inoculated EPPO differential potato varieties obtained with the Synchytrium endobioticumspecific TaqMan polymerase chain reaction (PCR) (PC-1) and a generic plant coxl TaqMan PCR. Samples visually scored as "symptomatic" are shown in red, asymptomatic plant parts are shown in green, and samples scored as "unclear" are shown in gray. A single inoculation site where the inoculum was not removed until sampling which resulted in rot is shown in black. Almost all variation $(97.3 \%)$ in the dataset is attributed to the S. endobioticum-specific $\mathrm{Cq}$ values.

TABLE 1. Final scoring results 35 to 59 days post inoculation of EPPO differential potato varieties with Synchytrium endobioticum pathotypes 1(D1), 2(G1), $6(\mathrm{O} 1)$, and $18(\mathrm{~T} 1)^{\mathrm{a}}$

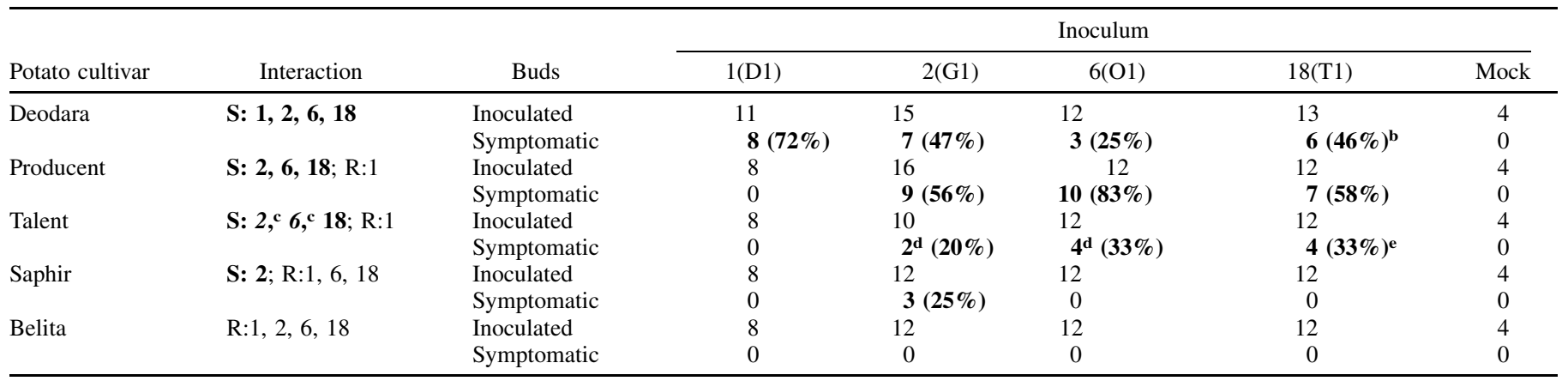

a The number of inoculated and symptomatic sites are shown for the respective inoculum sources. Percentages of symptomatic sites are shown in brackets. The susceptible (S) or resistant (R) interaction for a given variety-pathotype combination based on the Glynne-Lemmerzahl method is listed under "Interaction". S interactions observed in the aboveground bioassay are shown in bold.

b Four samples were initially scored as "unclear" but TaqMan verified.

c Slightly susceptible reactions in tuber based assays: nonnecrotic sori fields are observed but not full wart formation (OEPP/EPPO 2017).

d Initially scored as "unclear" but TaqMan verified.

e One additional sample was scored as "unclear". 
aboveground plant parts. In the belowground plant parts, however, 23 to 500 non-S. endobioticum Chytridiomycota transcripts were detected. Ascomycota hits were obtained in both aboveground and belowground plant parts representing species of Fusarium and Verticillium, although with significantly higher numbers of transcripts in the latter group $(t$ test, $P<0.001)$. Insect and nematode transcripts were identified in some of the aboveground samples and in all the belowground plant parts. Particularly in the belowground samples, the number and proportion of nematode hits was high, and were believed to originate from the soilborne bacteria-feeding Caenorhabditis elegans. Finally, on average, a quarter of all contigs obtained from the aboveground plant parts
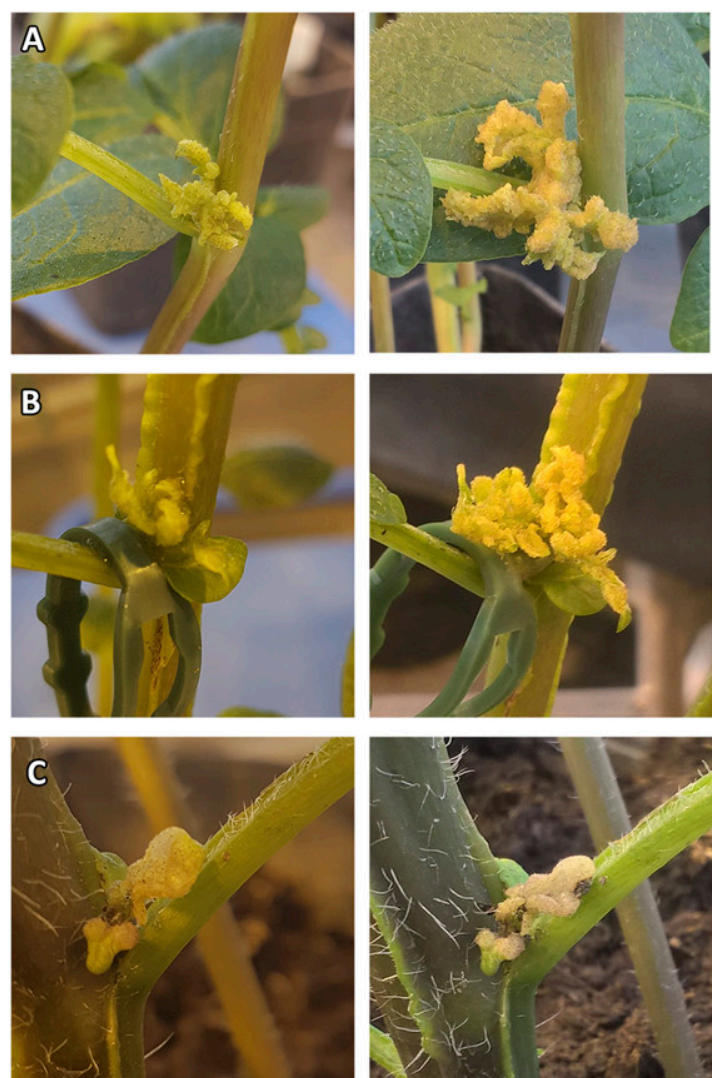

$22 \mathrm{dpi}$

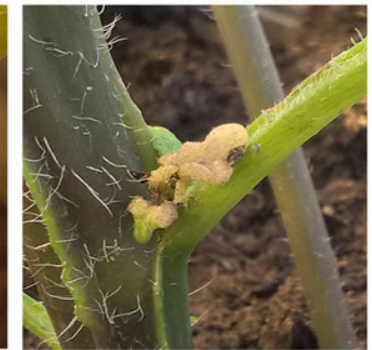

$29 \mathrm{dpi}$
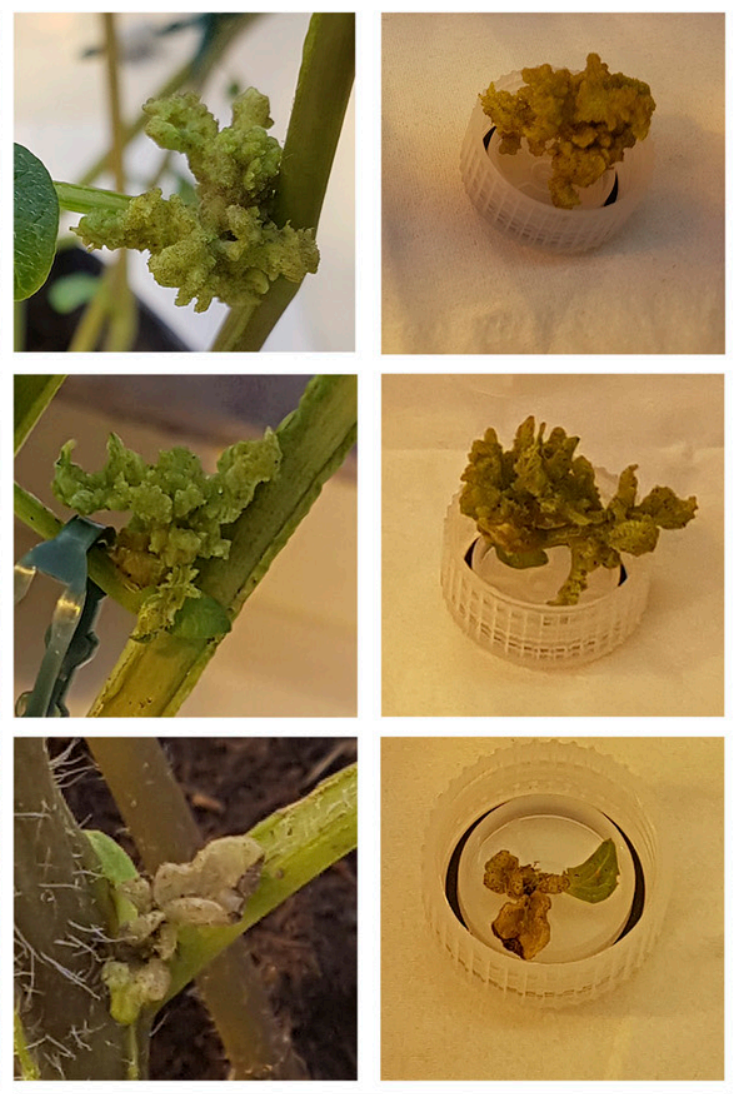

$35 \mathrm{dpi}$
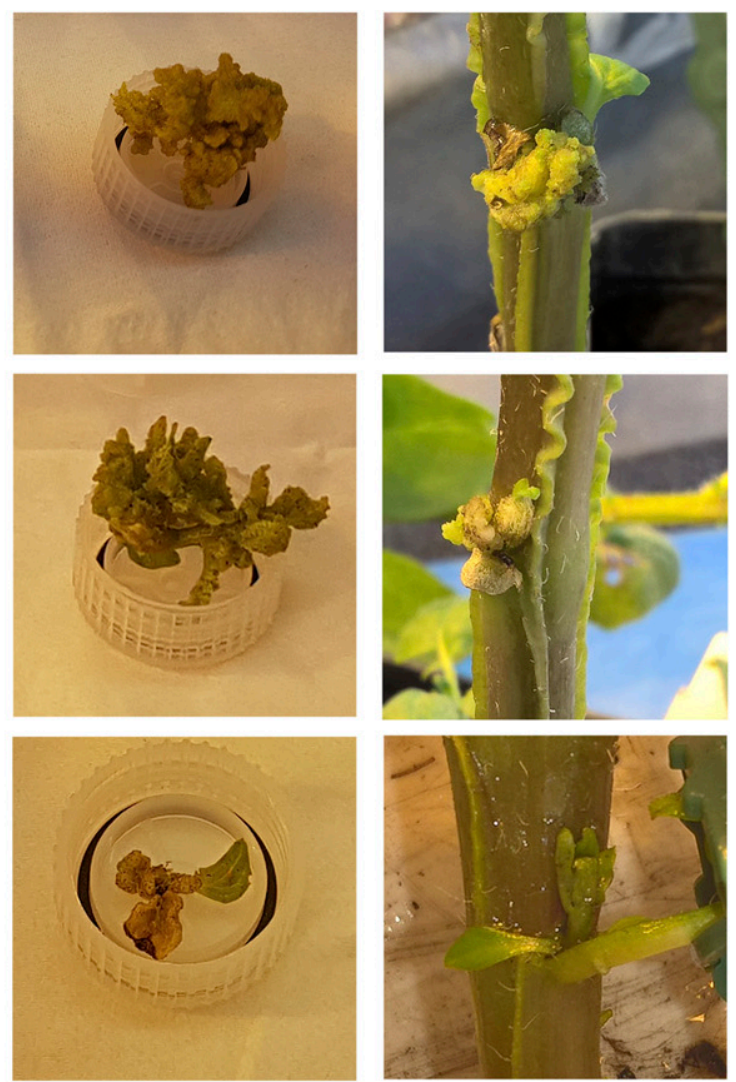

59 dpi

Fig. 4. Development of symptoms of Synchytrium endobioticum inoculated axillary buds at 22 days postinoculation (dpi) until sampling at 35 dpi. All visibly malformed tissue was removed but outgrowth of new malformed tissue was observed at 59 dpi. A, Producent (plant 1, bud 3) inoculated with pathotype 18(T1); B, Producent (plant 3, bud 2) inoculated with pathotype 2(G1); and C, Deodara (plant 3, bud 1) inoculated with pathotype 1(D1).

TABLE 2. Statistics RNAseq analysis

\begin{tabular}{|c|c|c|c|c|c|c|c|}
\hline Sample, pathotype & Sample & Total reads & $\begin{array}{l}\text { Reads mapped to } \\
\text { SeMB42 (\%) }\end{array}$ & $\begin{array}{l}\text { Reads mapped to } \\
\text { potato }(\%)\end{array}$ & $\begin{array}{l}\text { Unmapped } \\
\text { reads }(\%)\end{array}$ & $\begin{array}{l}\text { SeMB42 genes with } \\
\text { TPM } \geq 3(\%)^{\mathrm{a}}\end{array}$ & $\begin{array}{l}\text { Contigs from } \\
\text { unmapped reads }\end{array}$ \\
\hline \multicolumn{8}{|c|}{ Malformed axillary bud } \\
\hline \multirow[t]{3}{*}{$1(\mathrm{D} 1)$} & 1 & $36,550,782$ & 3.3 & 90.1 & 7 & 87 & 2,928 \\
\hline & 2 & $37,888,706$ & 1.6 & 92.3 & 6 & 81 & 2,762 \\
\hline & 3 & $37,075,286$ & 0.8 & 94.5 & 5 & 73 & 1,458 \\
\hline \multirow[t]{3}{*}{$2(\mathrm{G} 1)$} & 4 & $37,876,324$ & 6.4 & 84.1 & 10 & 90 & 10,156 \\
\hline & 5 & $37,763,618$ & 2.8 & 93.2 & 4 & 56 & 1,453 \\
\hline & 6 & $35,817,218$ & 1.5 & 94.2 & 4 & 85 & 1,720 \\
\hline \multirow[t]{3}{*}{$6(\mathrm{O} 1)$} & 7 & $39,614,686$ & 1.4 & 93.8 & 5 & 61 & 2,208 \\
\hline & 8 & $37,843,864$ & 1.0 & 90.4 & 9 & 60 & 3,952 \\
\hline & 9 & $38,196,934$ & 3.4 & 91.7 & 5 & 89 & 1,784 \\
\hline \multirow[t]{3}{*}{ 18(T1) } & 10 & $38,520,214$ & 0.4 & 92.8 & 7 & $4^{b}$ & 3,784 \\
\hline & 11 & $35,697,718$ & 1.0 & 93.5 & 6 & 68 & 2,752 \\
\hline & 12 & $39,945,608$ & 5.2 & 85.2 & 10 & 91 & 1,919 \\
\hline \multicolumn{8}{|c|}{$\begin{array}{l}\text { Resting spores extracted } \\
\text { from warted tubers }\end{array}$} \\
\hline \multirow[t]{4}{*}{$1(\mathrm{D} 1)$} & MB42+polyA & $95,754,584$ & 41.8 & 0.6 & 58 & 88 & 10,328 \\
\hline & MB42-polyA & $99,270,952$ & 42.5 & 0.6 & 57 & 91 & 40,935 \\
\hline & MB42+ribo- & $122,267,432$ & 16.1 & 2.0 & 82 & 91 & 85,248 \\
\hline & MB42-ribo- & $102,206,278$ & 18.1 & 9.2 & 73 & 92 & 96,796 \\
\hline
\end{tabular}

${ }^{a}$ TPM $=$ transcripts per kilobase million.

b This number is an overestimation of the true expression as a result of the bias introduced by TPM in low expressed datasets. 
did not produce significant hits, compared with approximately $12 \%$ in contigs from the belowground plant parts.

\section{DISCUSSION}

Bioassays are important tools to study the interaction between pathogens and their hosts. In many pathosystems, they are exploited on a differential set of genotypes to determine pathogen virulence or to group pathogens in races or pathotypes. For S. endobioticum, the tuber-based Spieckermann and Glynne-Lemmerzahl bioassays are widely used for potato resistance screening and pathotype identification. Infection of micropropagated plantlets has been described as an alternative to the belowground tuber-based assays (Hampson 1992; Hampson et al. 1997) but these methods were not adopted by the research community. With the publication of the genomes of two S. endobioticum isolates, representing different pathotypes and geographical origins (B. T. L. H. van de Vossenberg, S. Warris, H. D. T. Nguyen, M. P. E. van Gent-Pelzer, D. L. Joly, H. C. van de Geest, P. J. M. Bonants, D. S. Smith, C. A. Lévesque, T. A. J. van der Lee, unpublished), these alternatives are of increasing interest if these alternative bioassays result in lower microbiological contaminations, or when monitoring of the infection process is easier or more synchronous. Such high-quality starting material can be instrumental in elucidating the interaction between host plant and pathogen on a molecular level. We propose that the aboveground assay described here is an improvement for two main reasons.

First, central to the plant-pathogen interaction are pathogen effector genes that facilitate infection and manipulation of the host plant. When the products of these effector genes are recognized bylthe plant $R$ genes, these effector genes are referred to as avirulence (Avr) genes.

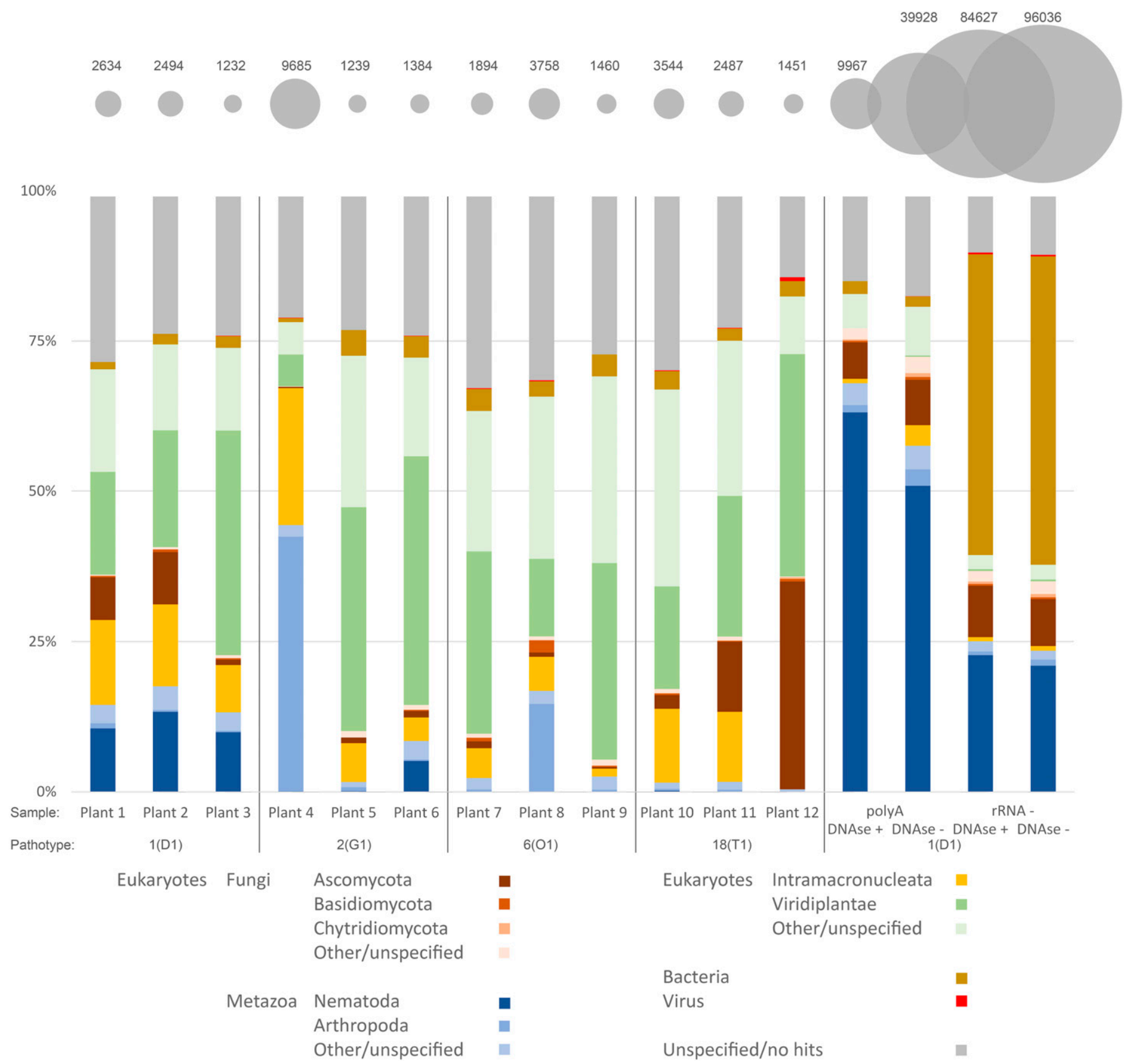

Fig. 5. Relative abundance of taxa other than Synchytrium endobioticum or potato, represented in aboveground plant parts and resting spores extracted from fresh warts on potato tubers. Bubble plots represent the number of contigs included in the blast analysis. Plants 1 to 3 were inoculated with pathotype 1(D1), plants 4 to 6 with 2(G1), plant 7 to 9 with 6(O1), and plants 10 to 12 with 18(T1). The last four samples represent the belowground-derived RNAseq datasets with different treatments $($ polyA $=$ polyA enrichment, $\mathrm{rRNA}-=$ ribosomal plant RNA depletion, and DNAse + or - treatment). 
The differences in the $R$ gene composition of the differential variety panel determines which Avr genes are recognized and form the basis for pathotype grouping. Assays based on pathotype-specific Avr genes (specific DNA markers or hypersensitivity responses [HR]) could, in time, replace the time-consuming and labor-intensive bioassays currently used for pathotyping, as has been demonstrated for Phytophthora infestans (Vleeshouwers et al. 2011). One way to demonstrate that a pathogen $A v r$ gene product is recognized by a host $R$ gene is by Agrobacterium tumefaciens-mediated transient transformation (agroinfiltration) (Van der Hoorn et al. 2000). In this system, plant leaves are infiltrated with $A$. tumefaciens suspensions carrying the gene of interest on a plant transformation vector. When expressed and recognized by plant receptors, defense responses are triggered, culminating in a visual HR. Agroinfiltration is highly efficient in leaves but much more complicated in other organs such as tubers and stems. To apply agroinfiltration as a verification method for $S$. endobioticum resistance, expression of plant $R$ genes in aboveground plant parts is required.

Second, in pathosystems where a multitude of species are present next to the studied host and pathogen, it is difficult to determine which responses originate from the pathosystem and which are related to other microbial factors. Particularly on the molecular level of the host, responses can be masked or obscured by the microbiome. This is even more the case for the soilborne pathogens because the rhizosphere has been shown to be much more complex than the phyllosphere in terms of microbial organisms (Lindow and Brandl 2003) and could, in the case of potato wart disease, promote accelerated decay of infected potato tissue. Hence, infected axillary buds could represent a more suitable material to study the interaction between S. endobioticum and its host on a molecular level.

Resistance in aboveground plant parts. Susceptible and resistant interactions with $S$. endobioticum in the EPPO differential set are identical in the aboveground bioassay and the tuber-based Spieckermann assays. None of the inoculated axillary buds of presumed resistant varieties produced symptoms. In contrast, when susceptible varieties were inoculated, wart-like symptoms where produced in 25 to $83 \%$ of the inoculations. This showed that the $S$. endobioticum $R$ genes from the EPPO differential set plants are expressed in axillary buds similar to the resistance in belowground organs. In addition, the percentage of symptom expression of susceptible interactions was similar to those observed in the Spieckermann assay, which ranged from 23 to $93 \%$. Strongly varying percentages of symptom expression that can be visually observed on potato tubers infected with $S$. endobioticum under controlled conditions have been reported as early as 1922, and have been persistent over time complicating the analysis (Hampson 1992). These inconsistencies have been attributed to a number of factors such as spore age and density, tuber and sprout age, potting medium or soil types, their porosity and texture, and watering regime (Hampson 1988). For the aboveground bioassay, properly fixing the inoculum and maintaining the moist environment at the inoculation site were regarded to be crucial for successful infection. In addition, we observed that potato variety Transit displayed poor growth in the moist environment, and this variety was removed from the study.

In the tuber-based bioassays, HR can be observed on etiolated sprouts in resistant interactions in the form of ladder-shaped necrotic spots. In our aboveground assay, similar spots were observed on shoots of the resistant potato variety Kuba that could be a manifestation of HR (Supplementary Fig. S6). However, the frequency at which these "lladdered HR" were observed was too low to serve as a hallmark for resistance scoring. When malformation was observed on the aboveground plant parts of susceptible plants, two main types of symptoms could be differentiate; that is, leaf malformation (Fig. 2D) and shoot malformations (Fig. 2E), of which the leaf malformation was encountered most frequently. It appears that normal development is halted in one case (leaf malformation), whereas it is more or less continued in the other (shoot malformations). We hypothesize that these differences could be caused by a disruption of apical dominance. The mechanism of apical dominance ensures the growth of only one meristem, ensuring clear features, and is based on auxins (Kebrom 2017). Also, the formation of aerial roots was observed for several infected axillary buds (Fig. 2E). This aerial root formation could also indicate a change in the auxin transport. In the tomato "aerial roots" (aer) mutant, auxin misaccumulation caused root formation along the stem (Mignolli et al. 2017).

After the end of the experiment (59 dpi), warts were discovered on belowground plant parts, although these were not inoculated, nor were resting spores added to the potting soil. Similarly, malformations of noninoculated aboveground plant parts, which were below an inoculated axillary bud, were observed. These ectopic proliferations of warted tissue occurred at low frequency and are believed to be caused by zoospores being transported by water dripping or flowing down the stem.

Pathogen proliferation was confirmed using a species-specific real-time PCR. Some background reaction with the plant matrix was observed, as was previously noted in an interlaboratory comparison (ILC) study by van de Vossenberg et al. (2018a). In the ILC, $\mathrm{Cq}$ values obtained with healthy plant samples were used to establish a Cq cut-off value $>30$ to eliminate false-positive results. Typically, infected potato tubers produced $\mathrm{Cq}$ values ranging from 15 to 25 in the ILC, which is similar to the range that was found for the symptomatic aboveground plant parts. The distribution of $\mathrm{Cq}$ values obtained from symptomatic and asymptomatic plant parts allowed us to distinguish between background reactions and pathogen proliferation, and were used to determine the pathogen proliferation of the plant parts scored as "unclear". The majority of inoculated axillary buds initially scored as unclear could be identified as infected (i.e., proliferation of the pathogen). These were mainly attributed to pathotype $2(\mathrm{G} 1)$ and $6(\mathrm{O} 1)$ inoculations on potato variety Talent. In one specific case, a relatively low $\mathrm{Cq}$ value (25.2) was obtained for a sample taken from a resistant interaction (18(T1) on variety Belita. In this particular case, the inoculum was not removed until sampling, which resulted in rotting of the inoculum. In this particular case, the inoculum may have resulted in a lower $\mathrm{Cq}$ value, not the proliferation of the pathogen.

In the EPPO diagnostic protocol, potato variety Talent is listed as resistant to pathotype 1 (D1) but weakly resistant to pathotypes 2(G1) and 6(O1). With this variety, no full wart formation is observed in the Glynne-Lemmerzahl bioassay (OEPP/EPPO 2017). In our bioassay, slight malformations were observed but not the severe malformations that were observed in susceptible interactions (Supplementary Fig. S7). The use of semiresistant varieties in differential sets poses the risk of ambiguous scoring of reactions types. Currently, the Glynne-Lemmerzahl bioassay is used most often for pathotyping and potato wart resistance determination. Five different reaction types are distinguished, ranging from extremely resistant to extremely susceptible. However, differences in the scoring and interpretation exist in different laboratories working with the bioassay (Flath et al. 2014). In this study, we demonstrated that verification of proliferation using molecular test may aid the assessment based on phenotypic or visual methods, providing a clearer distinction between the resistance or susceptibility of a variety for a given isolate of the pathogen. The use of semiresistant varieties should also be avoided for the production of starting inoculum because this may result in population shift as a result of virulent genotype selection. For $S$. endobioticum, it was demonstrated that a pathotype $1(\mathrm{D} 1)$ isolate produced a pathotype $6(\mathrm{O} 1)$ phenotype after two multiplications on a semiresistant potato variety (van de Vossenberg et al. 2018b), and it was suggested that both cognate (Avr) and noncognate (avr) genotypes coexist within the pathogen population. S. endobioticum growth on the semiresistant variety caused a selection against the Avr genotypes in the population, and the corresponding change in phenotype. In agronomical practices, plants that do not provide full resistance against certain isolates could also reshape the $S$. endobioticum 
population, selecting for genotypes with increased virulence. This could be the case for Talent and related genotypes in their interactions with pathotypes $2(\mathrm{G} 1)$ and $6(\mathrm{O} 1)$. We recommend additional research on this topic and caution against the use of semiresistant varieties in practice because they could be stepping stones for the pathogen.

With the bioassay presented in this article, the resistance and susceptibility responses of differentially resistant potato varieties to S. endobioticum pathotypes were equal in aboveground plant parts and the tuber-based bioassays. This suggests that $S$. endobioticum $R$ genes are expressed in both etiolated belowground sprouts and green aboveground organs. Our findings open up possibilities to test candidate Avr genes using leaf-based A. tumefaciens-mediated transient transformation assays.

Aboveground versus belowground. Almost all (90 to 96\%) RNAseq data obtained from the aboveground bioassay belong to either $S$. endobioticum or potato. This is in contrast to the belowground-derived samples, in which only 18 to $43 \%$ of the data belonged to the pathogen or its host. In the belowground-derived samples, the majority of reads were from other soilborne organisms or microorganisms. Even though, in the aboveground plant parts, transcripts of other prokaryotic and eukaryotic biological agents were identified, they were significantly less compared with the belowground-derived RNAseq data. The absence of soilborne saprobic pathogens could be an advantage of using the aboveground bioassays because these organisms influence the plant and potentially also the pathogen transcriptome. The majority of reads in the aboveground samples represent potato transcripts but still more than half of these samples show expression at TPM $>3$ in more than $70 \%$ of all S. endobioticum genes. Resting spores extracted from fresh warts have relatively high percentages of pathogen-specific reads but have almost no potato-derived reads. The proportion of potato-derived reads in the aboveground samples enables identification of differentially expressed plant hormone pathways such as auxin production and transport as a result of pathogen proliferation.

In one of the samples (pathotype 18(T1), plant 10), the total number of reads mapping to $S$. endobioticum was very low, resulting in a bias in the normalized read coverage score giving an overestimation of the expression of $S$. endobioticum genes. It is known that normalization methods such as TPM and reads per kilobase million can introduce biases in such situations (Dillies et al. 2013). Improvement could be made by also sampling at a later stage, when the symptoms have advanced further and more $S$. endobioticum biomass is accumulating. The biomass ratio between $S$. endobioticum and potato can be assessed by the use of the TaqMan PCR of S. endobioticum and the plant coxl that we applied in this study.

Studying the molecular pathogen-host interaction of soilborne obligate biotrophic organisms represents a unique challenge because the microbiome potentially interacts with both host and pathogen. This can obscure the interaction of the pathosystem. In general, infected tissues from the aboveground bioassay were less prone to rot compared with tissue from the tuber-based bioassay. Using the aboveground bioassay, the interaction can be studied by assessing both pathogen and host-derived transcripts with significantly fewer and less diverse contaminants, allowing studies of transcriptional responses of the plant to $S$. endobioticum infection and the ability to distinguish reactions to other microbes.

Closing remarks. Bioassays for S. endobioticum pathotyping and resistance determination are time consuming and labor intensive. Also, they require expertise that has to be developed over many years to visually assess the reaction types. Even though they have their challenges in terms of standardization, harmonization, and repeatability of test results obtained, they are fit for the purposes of the laboratories working with these methods. Imple-menting new bioassays implies that experts have to familiarize themselves with the art of the new method. Laboratories may not have the time or expertise to implement new methods and to test different methods in parallel. This possibly explains why the alternative bioassay described by Hampson (Hampson 1992; Hampson et al. 1997) was not adopted despite advantages such as increased sensitivity, higher success rates, and year-round application. Nevertheless, bioassays such as the one described by Hampson and the one from our study could have a potential use in conventional breeding programs. Their adoption by the community will depend on advantages that are not provided by other assays. We see clear advantages in breeding because our assay can be directly used on potato plants. Currently, it takes at least 2 years to obtain sufficient tubers of a new variety for $S$. endobioticum pathotype resistance screening. With our aboveground bioassay, this could be reduced to 1 year because clonally propagated cuttings from seedlings can be used in this assay. Also, other solanaceous species could represent new potato wart resistance sources. Nontuber-bearing species or species with poor tuber formation cannot be tested with the current tuber-based bioassays. With our assay, these now can be screened for potato wart resistance because no tubers are required, unlocking the potential of these species for new potato wart resistance.

\section{ACKNOWLEDGMENTS}

We thank R. Strijker (Hilbrands Laboratorium BV) for maintaining plants; R. G. F. Visser and H. van Eck (Wageningen University and Research, The Netherlands) for their support and advice on the project; Averis Seeds BV, Böhm-Nordkartoffel Agrarproduktion GmbH \& Co. OHG, Danespo, HZPC Holland BV, C. Meijer BV, SaKa Pflanzenzucht $\mathrm{GmbH} \& \mathrm{Co} . \mathrm{KG}$, and Teagasc for their involvement in the public-private partnership that was formed to fund this study; and D. S. Smith (Canadian Food Inspection Agency) for critically reviewing the manuscript before submission.

\section{LITERATURE CITED}

Baayen, R. P., Cochius, G., Hendriks, H., Meffert, J. P., Bakker, J., Bekker, M., van den Boogert, P. H. J. F., Stachewicz, H., and van Leeuwen, G. C. M. 2006. History of potato wart disease in Europe-A proposal for harmonisation in defining pathotypes. Eur. J. Plant Pathol. 116:21-31.

Bonants, P. J. M., van Gent-Pelzer, M. P. E., van Leeuwen, G. C. M., and van der Lee, T. A. J. 2015. A real-time TaqMan PCR assay to discriminate between pathotype 1 (D1) and non-pathotype 1 (D1) isolates of Synchytrium endobioticum. Eur. J. Plant Pathol. 143:495-506.

Buchfink, B., Xie, C., and Huson, D. H. 2015. Fast and sensitive protein alignment using DIAMOND. Nat. Methods 12:59-60.

Çakır, E., Van Leeuwen, G. C. M., Flath, K., Meffert, J. P., Janssen, W. A. P., and Maden, S. 2009. Identification of pathotypes of Synchytrium endobioticum found in infested fields in Turkey. Bull. OEEP/EPPO Bull. 39: 175-178.

Camacho, C., Coulouris, G., Avagyan, V., Ma, N., Papadopoulos, J., Bealer, K., and Madden, T. L. 2009. BLAST+: Architecture and applications. BMC Bioinf. 10:421.

Curtis, K. M. 1921. IX.-The life-history and cytology of Synchytrium endobioticum (Schilb.), Perc., the cause of wart disease in potato. Philos. Trans. R. Soc. Lond., B Contain. Pap. Biol. Character 210:409-478.

Dillies, M.-A., Rau, A., Aubert, J., Hennequet-Antier, C., Jeanmougin, M., Servant, N., Keime, C., Marot, G., Castel, D., Estelle, J., Guernec, G., Jagla, B., Jouneau, L., Laloë, D., Le Gall, C., Schaëffer, B., Le Crom, S., Guedj, M., and Jaffrézic, F. 2013. A comprehensive evaluation of normalization methods for Illumina high-throughput RNA sequencing data analysis. Brief. Bioinf. 14:671-683.

Flath, K., Przetakiewicz, J., van Rijswick, P. C. J., Ristau, V., and van Leeuwen, G. C. M. 2014. Interlaboratory tests for resistance to Synchytrium endobioticum in potato by the Glynne-Lemmerzahl method. Bull. OEEP/EPPO Bull. 44:510-517.

Glynne, M. D. 1925. Infection experiments with wart disease of potatoes. Synchytrium endobioticum (Schilb.) Perc. Ann. Appl. Biol. 12:34-60.

Hampson, M. C. 1988. Control of potato wart disease through the application of chemical soil treatments: A historical review of early studies (19091928). Bull. OEEP/EPPO Bull. 18:153-161.

Hampson, M. C. 1992. A bioassay for Synchytrium endobioticum using micropropagated potato plantlets. Can. J. Plant Pathol. 14:289-292.

Hampson, M. C. 1993. History, biology and control of potato wart disease in Canada. Can. J. Plant Pathol. 15:223-244. 
Hampson, M. C., Coombes, J. W., and Debnath, S. C. 1997. Dual culture of Solanum tuberosum and Synchytrium endobioticum (pathotype 2). Mycologia 89:772-776.

Kebrom, T. H. 2017. A growing stem inhibits bud outgrowth-The overlooked theory of apical dominance. Front. Plant Sci. 8:1874.

Lemmerzahl, J. 1930. Neues vereinfachtes Infektionsverfahren zur Prüfung von Kartoffelsorten auf Krebsfestigkeit. Züchter 2:288-297.

Lex, A., Gehlenborg, N., Strobelt, H., Vuillemot, R., and Pfister, H. 2014. UpSet: Visualization of intersecting sets. IEEE Trans. Vis. Comput. Graph. 20:1983-1992.

Lindow, S. E., and Brandl, M. T. 2003. Microbiology of the phyllosphere. Appl. Environ. Microbiol. 69:1875-1883.

Mignolli, F., Mariotti, L., Picciarelli, P., and Vidoz, M. L. 2017. Differential auxin transport and accumulation in the stem base lead to profuse adventitious root primordia formation in the aerial roots (aer) mutant of tomato (Solanum lycopersicum L.). J. Plant Physiol. 213:55-65.

Millett, B. P., Gao, L., Iorizzo, M., Carputo, D., and Bradeen, J. M. 2015. Potato tuber blight resistance phenotypes correlate with $\mathrm{RB}$ transgene transcript levels in an age-dependent manner. Phytopathology 105:1131-1136.

Moore, W. C. 1957. The breakdown of immunity from potato wart disease. Outlook Agric. 1:240-243.

Noble, M. G., and Glynne, M. D. 1970. Wart disease of potatoes. FAO Plant Prot. Bull. 18:125-135.

OEPP/EPPO. 2004. Synchytrium endobioticum PM 7/28 (1). Bull. OEEP/ EPPO Bull. 34:213-218.

OEPP/EPPO. 2017. Synchytrium endobioticum PM 7/28 (2). Bull. OEEP/ EPPO Bull. 47:420-440.

Ondov, B. D., Bergman, N. H., and Phillippy, A. M. 2011. Interactive metagenomic visualization in a Web browser. BMC Bioinf. 12:385.

Przetakiewicz, J. 2015a. First report of new pathotype 39(P1) of Synchytrium endobioticum causing potato wart disease in Poland. Plant Dis. 99:285.

Przetakiewicz, J. 2015b. The viability of winter sporangia of Synchytrium endobioticum (Schilb.) Perc. from Poland. Am. J. Potato Res. 92:704-708.

Schilberszky, K. 1896. Ein neuer Schorfparasit der Kartoffelknollen. Ber. Deut. Bot. Ges. 14:36-37.

Smith, I. M., McNamara, D. G., Scott, P. R., Holderness, M., and Burger, B. 1997. Quarantine Pests for Europe-Data Sheets on Quarantine Pests for the European Union and for the European and Mediterranean Plant Protection Organization. CAB International, Wallingford, UK

Spieckermann, A. K. P. 1924. Testing potatoes for wart resistance. Dtsch. Landwirtsch. Presse 51:114-115.

The Potato Genome Sequencing Consortium. 2011. Genome sequence and analysis of the tuber crop potato. Nature 475:189-195.

Ullrich, J. 1962. Morphologische und anatomische Untersuchungen über die durch Synchytrium endobioticum (Schilb.) Perc. bei der Kartoffel ausgelöste Gallbildung. J. Phytopathol. 44:57-75.

van de Vossenberg, B., Westenberg, M., Adams, I., Afanasenko, O., Besheva, A., Boerma, M., Choiseul, J., Dekker, T., Flath, K., van Gent-Pelzer, M., Heungens, K., Karelov, A., Kibildiene, I., Przetakiewicz, J., Schlenzig, A., Yakovleva, V., and van Leeuwen, G. 2018a. Euphresco Sendo: An international laboratory comparison study of molecular tests for Synchytrium endobioticum detection and identification. Eur. J. Plant Pathol. 151: 757-766.

van de Vossenberg, B. T. L. H., Brankovics, B., Nguyen, H. D. T., van Gent-Pelzer, M. P. E., Smith, D., Dadej, K., Przetakiewicz, J., Kreuze, J. F., Boerma, M., van Leeuwen, G. C. M., André Lévesque, C., and van der Lee, T. A. J. 2018b. The linear mitochondrial genome of the quarantine chytrid Synchytrium endobioticum; insights into the evolution and recent history of an obligate biotrophic plant pathogen. BMC Evol. Biol. 18:136.

Van der Hoorn, R. A., Laurent, F., Roth, R., and De Wit, P. J. 2000. Agroinfiltration is a versatile tool that facilitates comparative analyses of Avr9/ Cf-9-induced and Avr4/Cf-4-induced necrosis. Mol. Plant-Microbe Interact. 13:439-446.

van Gent-Pelzer, M. P. E., Krijger, M., and Bonants, P. J. M. 2010. Improved real-time PCR assay for detection of the quarantine potato pathogen, Synchytrium endobioticum, in zonal centrifuge extracts from soil and in plants. Eur. J. Plant Pathol. 126:129-133.

Vleeshouwers, V. G. A. A., Raffaele, S., Vossen, J. H., Champouret, N., Oliva, R., Segretin, M. E., Rietman, H., Cano, L. M., Lokossou, A., Kessel, G., Pel, M. A., and Kamoun, S. 2011. Understanding and exploiting late blight resistance in the age of effectors. Annu. Rev. Phytopathol. 49:507-531.

Weiss, F. 1925. The conditions of infection in potato wart. Am. J. Bot. 12: 413-443. 